\title{
РЕЗУЛЬТАТИВНІСТЬ ПРОГРАМИ ПСИХОЛОГІЧНОЇ КОРЕКЦІЇ РЕСОЩАЛІЗАЦІЇ ОСОБИСТОСТІ ПІСЛЯ ЗВІЛЬНЕННЯ ВІД ВІДБУВАННЯ ТЕРМІНУ ПОКАРАННЯ
}

УдК: $159.9: 316.6$

\section{Сорока Анатолій Володимирович}

Кандидат психологічних наук, доцент, доиент кафедри прикладної психології Харківського національного університету імені В. Н. Каразіна, м Харків (Украӥна)

\begin{abstract}
Анотація. $\quad$ статті висвітлено дослідження апробації окремих результатів авторської програми психологічної корекцї ресоціалізації особистості після звільнення від відбування терміну покарання відповідно до виконання запропонованого нами системокомплексу [2 - 7]. Практична значущістьь дослідження полягає в апробації й успішному впровадженні результатів дослідження (підтверджено актами впровадження), а саме: «Психодіагностичною та психокорекиійною програмами дослідження готовності до ресочіалізації особистості після звільнення від відбування терміну покарання» у иентрах соціальної адаптації Харківської й Сумської областей України. Результати дослідження використовуються в практичній діяльності психологів установ виконання покарань, пробації вищезазначених областей, а також під час проведення занять у системі професійної підготовки й підвищення кваліфікаџіï психологів установ виконання покарань, пробаџії України.

Матеріали дослідження можуть бути використані в роботі з неповнолітніми правопорушниками; із засудженими, які відбувають покарання в колонії-поселенні або без ізолящії від суспільства; у таких сферах психологї, як юридччна, превентивна, ювенальна та iнui.
\end{abstract}

Ключові слова: системний підхід, системо-комплекс, психокорекиійна програма, ресойіалізаичія особистості.

Постановка проблеми. Ресоціалізація особистості після звільнення від відбування терміну покарання сприяє попередженню рецидивної злочинності особистості, яка перебуває у відповідних установах соціальної адаптації, а також прискорює процес адаптації до сучасного життя в суспільстві.

На сьогодні проблема ресоціалізації осіб, звільнених із місць позбавлення волі та звільнених від відбування покарання з випробуванням, не набула належного розвитку у вітчизняній системі пробації України.

Пробація - система наглядових і соціально-виховних заходів, що застосовуються за рішенням суду та згідно із законом до засуджених, виконання певних видів криміналь- 
них покарань, не пов'язаних із позбавленням волі, та забезпечення суду інформацією, що характеризує обвинуваченого. Пробаційна програма - програма, що призначається за рішенням суду особі, звільненій від відбування покарання з випробуванням, і передбачає комплекс заходів, спрямованих на корекцію соціальної поведінки або іiі окремих виявів, формування соціально сприятливих змін особистості, які можна об'єктивно перевірити [1].

Можливості підвищення професійної компетентності психологів пробації України у зв'язку з означеною проблемою використовуються недостатньо. Можна констатувати, що психологічна робота пробації ще не вийшла за межі окремих експериментів і не стала відпрацьованою й науково обгрунтованою системою. Цьому перешкоджають не лише нечисленність психологів пробації й слабке методичне забезпечення їхньої діяльності, а й недостатня наукова обгрунтованість підходів до створення технологій відновлення і розвитку в суб'єктів пробації життєво важливих умінь і якостей, необхідних для їх успішної реінтеграції в суспільство. Дефіцит ефективних технологій психологічної ресоціалізації звільнених із місць позбавлення волі осіб ускладнює профілактичну роботу, спрямовану на ослаблення десоціалізувального впливу тюремного середовища, оскільки завдання (ресоціалізація, профілактика, психокорекція) взаємопов'язані.

Практична значущість дослідження полягає в апробації й успішному впровадженні результатів дослідження (підтверджено відповідними актами впровадження), а саме: «Психо-діагностичною та психокорекційною програмами дослідження готовності до ресоціалізації особистості після звільнення від відбування терміну покарання» у відповідних центрах соціальної адаптації Харківської й Сумської областей України. Результати дослідження використовуються в практичній діяльності психологів установ виконання покарань, пробації вищезазначених областей, а також під час проведення занять у системі професійної підготовки й підвищення кваліфікації психологів установ виконання покарань, пробації України.

Матеріали дослідження можуть бути використані в роботі з неповнолітніми правопорушниками; із засудженими, які відбувають покарання в колонії-поселенні або без ізоляції від суспільства; у таких сферах психології, як юридична, превентивна, ювенальна та інші.

Аналіз останніх досліджень і публікацій. Дослідженнями зазначеної проблеми зай-

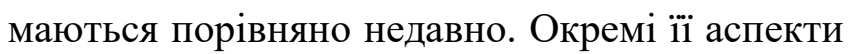
знайшли відображення в роботах педагогічних психологів (соціалізація особистості в ускладнених умовах), юридичних психологів (психологічна сутність злочину і покарання), пенітенціарних психологів (психологія особистості, яка відбуває покарання) і т. п. У педагогіці й психології ще з 30-их років минулого століття 3'явився інтерес до перевиховання 
злочинців. У зв'язку з цим заслуговують на увагу праці Ю. М. Антоняна, М. А. Бєляєва, В. I. Гуськова, М. І. Волошина, А. Ф. Зелінського, І. А. Стручкова, І. В. Шмарова. Проблему соціальної реадаптації особистості частково висвітлено в дослідженнях В. В. Голини, I. М. Даниліна, В. С. Потьомкіна та ін.

У 90-их роках започатковано розв'язання проблеми ресоціалізації засуджених у місцях позбавлення волі та соціальної адаптації осіб, звільнених від відбування покарання, однієї з центральних у боротьбі зі злочинністю. У кримінологічному плані вивчення цієї проблеми є одним із напрямів попередження рецидивної злочинності. В. М. Трубников уважає, що соціальна адаптація - «це міст, яким звільнені повертаються в суспільство, відновлюють соціально корисні зв'язки і правовий статус громадянина» $[8$, с. 3$]$.

На сьогодні значний внесок у дослідження теорії і практики ресоціалізації особистості зробив Ю. М. Швалб, який стверджує, що «ресоціалізація здійснюється тільки як мотивована і вольова дія самого індивіда. Людину не можна ресоціалізувати «ззовні» - їй можна тільки надати соціальну або психологічну допомогу в рішенні змінити своє життя. Ресоціалізація здійснюється як процес зміни індивідом своєї власної системи соціальних настанов, соціальних зв'язків і соціальних взаємодій. Така зміна, безумовно, $є$ надзвичайно складною в психологічному плані і настільки ж важкою в діяльнісному плані» [9, с. 30].
Крім того, у більшості опублікованих досліджень переважає практичний аспект: тією чи іншою мірою аналізуються труднощі, що виникають у людини, яка потрапляє до місць позбавлення волі або звільняється 3 них. Узагальненого ж теоретичного аналізу проблеми ресоціалізації особистості після звільнення від відбування терміну покарання ще немає, особливо iï психолого-педагогічних аспектів. Відсутні також комплексні дослідження механізмів ресоціалізації, у яких би розглядалася взаємодія особистості й середовища виправної установи, та проблеми ресоціалізації особистості після звільнення від відбування терміну покарання.

Водночас слід зазначити, що юристи, педагоги і психологи єдині в думці, що виправленню особистості сприяє ряд чинників: режим утримання засуджених, соціальновиховна та психологічна робота, громадська робота, проведена співробітниками установи, організація дозвілля в колонії.

Проведений аналіз літератури переконує нас у тому, що на сьогодні залишилися мало вивченими психолого-педагогічні чинники ресоціалізації та реадаптації особистості в пенітенціарній установі, а особливо недостатньо розкрито роль психологічної служби в наданні допомоги й підтримки ресоціалізації особистості після звільнення від відбування терміну покарання.

Таким чином, виявляється, що в науці мало уваги приділяється саме психодіагности- 
чній і психокорекційній роботі щодо ресоціалізації особистості після звільнення від відбування терміну покарання.

Мета статті: визначити окремі результати дослідження після застосування нами авторської програми психологічної корекції ресоціалізації особистості після звільнення від відбування терміну покарання.

Дослідження проводилися на базі чотирьох установ Харківської й Сумської областей України. Вибірка дослідження складає загальною кількістю 100 осіб чоловічої статі (перші шість місяців після звільнення від відбування терміну покарання). 3 неї виділилися 48 досліджуваних, які за власним бажанням входили до чотирьох експериментальних груп та відповідали таким критеріям:

1) їхні внутрішні переконання щодо змін власного життя на краще були настільки бажаними, що вони з великим задоволенням брали участь у проведенні апробації психокорекційної програми;

2) відсутність наркотичної, алкогольної або ігрової залежності;

3) досліджувані в групах були близькими за віком.

Їм було надано можливість брати участь у груповій роботі протягом 2,5 місяців по 1 заняттю на тиждень тривалістю 4 академічні години кожне (усього 36 годин).

Таким чином, було сформовано 4 експериментальні групи:

- перша група досліджуваних (молодь) - 24 чоловіки, віком від 28 до 39 років - поділяється на 2 підгрупи по 12 осіб;

- друга група досліджуваних (старші за віком) - 24 чоловіки, віком від 40 до 50 років - поділяється на 2 підгрупи по 12 осіб.

Загальна кількість досліджуваних експериментальних груп становить 48 чоловіків.

Контрольну групу склали 52 досліджувані, які увійшли до вибірки на початковому етапі дослідження, але не брали участі в груповій роботі; із ними в різних установах соціальної адаптації проводилась інша робота 3 ресоціалізації.

Слід спеціально наголосити, що в психокорекційному тренінгу не брали участі особи, які мають патопсихологічні відхилення.

Досягнуті в процесі науковоекспериментальної роботи результати порівнювалися й оцінювалися за показниками «Системи иіннісно-нормативної сфери особистосmi», а саме: шкали базових переконань особистості, шкали загальної комунікативної толерантності особистості, шкали схильності до агресії особистості у відносинах з оточенням. Також за показниками «Системи вольової саморегуляиії особистості», до якої належать такі показники психологічної характеристики: шкала вольової саморегуляції особистості, шкала контролю за дією (показник самоконтролю) особистості, шкала здатності до самоорганізації особистості. На нашу думку, негативні показники вищеперерахованих змінних зумовлюють недостатню ресоціалізацію особистості 
після звільнення від відбування терміну покарання в сучасному суспільстві.

Отримані на початковому етапі дослідження дані ми докладно описали в наших попередніх публікаціях [2-7]. Основною метою проведення психокорекційної програми 3 досліджуваних характеристик є виправлення негативних показників відповідних змінних досліджуваного нами системо-комплексу, а саме: вирівнювання загального відставання в
1. Динаміка показника «Шкали загальної комунікативної толерантності» і iї субшкал наочно показано в таблиці 1.

Наочно динаміку зміни середніх показників загального рівня сформованості субшкали загальної комунікативної інтолерантності на початковому і заключному етапах роботи із досліджуваними показано на рис. 1. Достовірність відмінностей, встановлена за допомогою t-критерію Стьюдента для

Таблиия 1.

\section{Розподіл досліджуваних за рівнями сформованості шкали загальної комунікатив- ної толерантності і її субшкал на початковому і заключному етапах роботи}

\begin{tabular}{|c|c|c|}
\hline $\begin{array}{c}\text { Рівень сформованості субшкал шкали загальної комуніка- } \\
\text { тивної толерантності }\end{array}$ & Початковий етап & $\begin{array}{l}\text { Після завершення ро- } \\
\text { боти }\end{array}$ \\
\hline \multicolumn{3}{|c|}{ Прагнення «підігнати» партнера під себе } \\
\hline Низький & 10 чол. $(23,65 \%)$ & 24 чол. (50\%) \\
\hline Середній & 14 чол. $(26,35 \%$ & 15 чол $(27,7 \%)$ \\
\hline Високий & 24 чол. $(50 \%)$ & 9 чол. $(22,3 \%)$ \\
\hline \multicolumn{3}{|c|}{ Прагнення перевиховати партнера } \\
\hline Низький & 11 чол. $(24,25 \%)$ & 26 чол. $(51,74 \%)$ \\
\hline Середній & 15 чол. $(27,7 \%)$ & 16 чол. $(28,11 \%)$ \\
\hline Високий & 22 чол. $(48,05 \%)$ & 6 чол. $(20,15 \%)$ \\
\hline \multicolumn{3}{|c|}{ Невміння пристосуватися до інших } \\
\hline Низький & 9 чол. $(23,5 \%)$ & 22 чол. $(48,05 \%)$ \\
\hline Середній & 16 чол. $(27,45 \%)$ & 18 чол. $(29,11 \%)$ \\
\hline Високий & 23 чол. $(49,05 \%)$ & 8 чол. $(22,84 \%)$ \\
\hline \multicolumn{3}{|c|}{ Невміння пробачати іншим помилки } \\
\hline Низький & 3 чол. $(1,74 \%)$ & 20 чол. $(47,25 \%)$ \\
\hline Середній & 20 чол. $(47,15 \%)$ & 18 чол. $(29,11 \%)$ \\
\hline Високий & 25 чол. $(51,11 \%)$ & 6 чол. $(23,64 \%)$ \\
\hline \multicolumn{3}{|c|}{ Використання себе як еталона } \\
\hline Низький & 29 чол. $(60,11 \%)$ & 33 чол. $(72,18 \%)$ \\
\hline Середній & 12 чол. $(24,5 \%)$ & 15 чол. $(27,82 \%)$ \\
\hline Високий & 7 чол. $(15,39 \%)$ & Не має \\
\hline
\end{tabular}

розвитку ціннісно-нормативної сфери й вольової саморегуляції особистості. Тому аналіз досягнень результатів дослідження ми продовжуємо з таких інтеграційних показників: залежних вибірок, свідчить про те, що на початок і завершення роботи із досліджуваними значущо відрізняються показники загального середнього показника інтолерантності ( $\mathrm{t}=$ 18,84 при $\mathrm{p}<0,00001)$, прагнення «підігнати» 
партнера під себе ( $\mathrm{t}=-17,24$ при $\mathrm{p}<0,00001)$, прагнення перевиховати партнера $\mathrm{t}=-18,64$ при $\mathrm{p}<0,00001)$, невміння пристосуватися до інших ( $\mathrm{t}=-17,96$ при $\mathrm{p}<0,00001)$, невміння пробачати іншим помилки $(\mathrm{t}=-18,56$, при $\mathrm{p}<$ $0,00001)$, використання себе як еталона $(\mathrm{t}=-$ 18,26 при $р<0,00001)$. Відмінності мають статистично значущий характер і свідчать про те, що рівень інтолерантності серед досліджуваних зменшився на завершальному етапі групової роботи.

2. Динаміку показника «Шкали схильності до агресії особистості» наочно показано

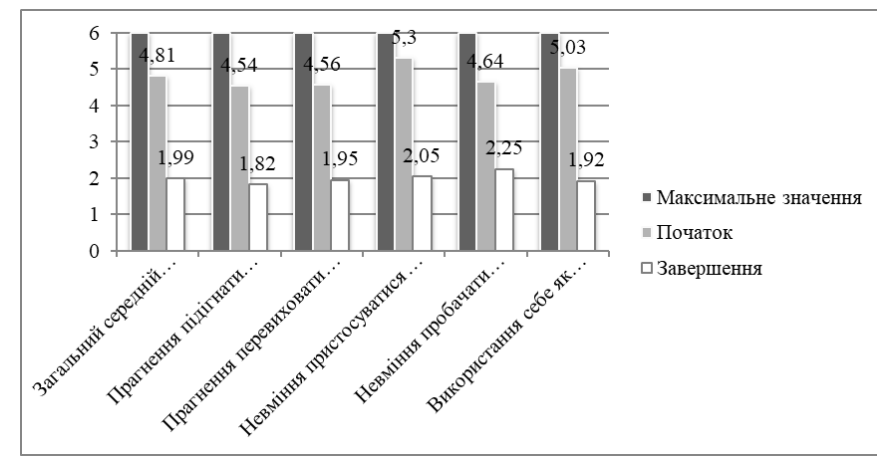

Рис. 1. Динаміка показників субшкали загальної комунікативної інтолерантності у досліджуваних (середнс значення).

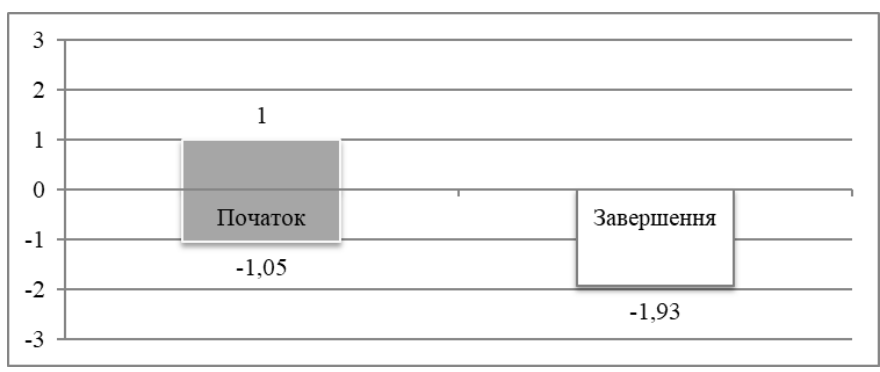

Рис. 2. Динаміка показників загального рівня схильності до агресії в досліджуваних (середнс значення). в таблиці 2 та на рис. 2.

Достовірність відмінностей, встановлена за допомогою t-критерію Стьюдента для Таблиия 2 Розподіл досліджуваних за рівнями
схильності до агресії на початковому і
авершальному етапах групової роботи

\begin{tabular}{|l|l|l|}
\hline $\begin{array}{l}\text { Рівні схильності } \\
\text { до агресії }\end{array}$ & $\begin{array}{l}\text { Початковий } \\
\text { етап }\end{array}$ & $\begin{array}{l}\text { Завершальний } \\
\text { етап }\end{array}$ \\
\hline Низький & $\begin{array}{l}3 \text { чол. } \\
(2,75 \%)\end{array}$ & 15 чол. (29,62\%) \\
\hline $\begin{array}{l}\text { Середній з тенденцією } \\
\text { до низького }\end{array}$ & $\begin{array}{l}13 \text { чол. } \\
(25,3 \%)\end{array}$ & 21 чол. (48,18\%) \\
\hline $\begin{array}{l}\text { Середній з тенденцією } \\
\text { до високого }\end{array}$ & $\begin{array}{l}\text { (2 чол. } \\
(47,15 \%)\end{array}$ & 12 чол. (22,2\%) \\
\hline Високий & $\begin{array}{l}(10 \text { чол. } \\
(24,8 \%)\end{array}$ & Немає \\
\hline
\end{tabular}

залежних вибірок, свідчить про те, що на початок і завершення групової роботи із досліджуваними значущо відрізняються показники загального середнього показника схильності до агресії ( $\mathrm{t}=-13,92$, при $\mathrm{p}<0,000001)$. Таким чином з'ясовано, що в процесі групової роботи із досліджуваними відбулося статистично значуще зниження загального середнього показника схильності до агресії: від показника високого рівня (+1) до низького рівня сформованості схильності до агресії $(-1,93)$. Отриманий результат свідчить про високу результативність групової роботи щодо корекції схильності до агресії в досліджуваних. 
Таким чином, за результатами апробації авторської програми психологічної корекції ресоціалізації досліджуваних у відповідних установах соціальної адаптації розподіл досліджуваних за рівнями сформованості показників досліджуваного нами системокомплексу на початковому і заключному етапах групової роботи визначив такі результати:

1) дослідження показало, що пропонована модель авторської програми психологічної корекції ресоціалізації досліджуваних зумовлює корекцію шкали загальної комунікативної толерантності і їі субшкал: прагнення «підігнати» партнера під себе, прагнення перевиховати партнера, невміння пристосуватися до інших, невміння пробачати іншим помилки, використання себе як еталона змінилися на статистично значущому рівні, тобто відбулася їх корекція (в окремих досліджуваних спостерігається зниження за змінними дуже високих показників і підвищуються низькі показники, що стосується загальної та інших типів толерантності, або інтолерантності). У досліджуваних на статистично значущому рівні зменшилися показники інтолерантних настанов особистості, що виявляються в процесі спілкування, а це свідчить про те, що в досліджуваних у процесі групової роботи відбулася переоцінка минулого і почав накопичуватися позитивний особистий досвід як запорука успішної їхньої посттюремної ресоціалізації та інтеграції в суспільство;

2) у результаті проведеної групової ро- боти помітно знизився в досліджуваних загальний рівень вираженості шкали схильності до агресії особистості від +1 бала в окремих досліджуваних (12 чол.) до - 1,93 бали в більшості досліджуваних. Відповідно до тестових норм, якщо показник «А» перевищує 0, це свідчить про підвищену агресивність. Якщо «А» дорівнює «0», це дозволяє припустити, що людина схильна до агресії по відношенню до тих, кого вона краще знає, але під час спілкування 3 чужими людьми успішно контролює свою агресію. Якщо показник «А» отримує мінусовий знак, то вияв агресії можливий лише в особливих значущих ситуаціях (що можна вважати нормою).

Таким чином, висунута нами гіпотеза про те, що негативні показники вищеперерахованих змінних зумовлюють недостатню ресоціалізацію особистості після звільнення від відбування терміну покарання в сучасному суспільстві доведена в процесі проведення психокорекційної роботи 3 4-ма експериментальними групами досліджуваних. У результаті роботи відбулися істотні зміни в цілому ряді показників досліджуваного нами системо-комплексу, вираженість яких на момент завершення дослідження порівняно $з$ його початком дає змогу стверджувати, що процес ресоціалізації досліджуваних відбувається успішно. Вісім досліджуваних після участі в програмі успішно одружилися (матеріальну допомогу їм надали відповідні благодійні та релігійні організації України) і щасливо жи- 
вуть у сім’ї, виховують дітей. А автор як голова громадської організації Північно-Східного міжрегіонального управління виконання покарань і пробації Міністерства юстиції України всіляко намагається надавати їм допомогу.

Перспективою наших подальших досліджень і публікацій буде розкриття результатів роботи після проведення психокорекційної програми із досліджуваними.

\section{Перелік використаних джерел:}

1. Закон України Про пробацію. Відомості Верховної Ради, 2015, № 13, ст.2.

2. Сорока A. В. Програми дослідження розвитку ефективності соціальної адаптації особистості після звільнення із пенітенціарних установ /А. В. Сорока // Проблеми екстремальної та кризової психології. Збірник наукових праць. Частина II. - Х.: НУЦЗУ, 2013. - С. 330-337.

3. Сорока A. В. Особливості показників базових переконань бездомної особи після звільнення від відбування покарання. /А. В. Сорока // Вісн. Харк. нац. ун. імені В. Н. Каразіна. Збірник наукових праць. - № 1095. Серія: Психологія. - 2014. Вип. 53. - С. 233-237.

4. Сорока А. В. Системний підхід до ресоціалізації особистості після звільнення від відбування покарання. /А. В. Сорока // Вісн. Харк. нац. ун. імені В. Н. Каразіна. Збірник наукових праць. - Серія «Психологія». Вип. 58. - 2015. - C. 147-151.

5. Сорока А. В. Психологические особенности социальной реадаптации лиц, освобождённых из мест лишения свободы. Современные проблемы прикладной юридической психологии [Электронный ресурс]: материалы I Респ. науч.-практ. конф., Минск, 23 нояб. 2016 г. / редкол.: И. А. Фурманов (отв. ред.) [и др.]. - Электрон. дан. (17,1 Мб). - Минск: Изд. центр БГУ, 2016. - С. 101 -106 .
6. Сорока А. В. Особливості ресоціалізації особистості після звільнення від відбування терміну покарання. Social Sciences and Psychology faculty: 25 years (progress, problems, perspectives) Republican scientificpractical conference of young researchers (17 April 2017). -Bak1 - 2017. - P. 77-81.

7. Soroka $A$. $V$. PSYCHOLOGICAL FEATURES OF PERSONALITY SELF GOVERNING IN THE PERIOD OF SOCIAL REHABILITATION. Proceedings of III International scientific conference «Science: new goals». London, SI Universum, 2017. - P. 43-53.

8. Трубников В. М. Социальная адаптация освобожденных от отбывания наказания. Харьков, 1990. - С. 3.

9. Швалб Ю. М. Психологія соціальної роботи: підручник /за ред. Ю. М. Швалба. - К.: «Основа», 2014. - С. 30.

\section{References (Transliteration):}

1. The Law of Ukraine on Probation. Information from the Verkhovna Rada, 2015, N 13, p.2.

2. Soroka A. V. Programs to study the development of the effectiveness of social adaptation of the individual after release from the penitentiary institutions /A. V. Soroka // Problems of extreme and crisis psychology. Collection of scientific works. Part II. - Kh.: NUTZU, 2013. - P. 330337.

3. Soroka A. V. Features of indicators of basic beliefs of a homeless person after release from serving a sentence. / AND. V. Soroka // Visn. Hark. Nats. Un. named after V.N. Karazin. Collection of scientific works. - N. 1095. - Series: Psychology. - 2014. Whip 53. - P. 233-237.

4. Soroka A. V. System approach to resocialization of personality after release from serving a sentence. /A. V. Soroka // Visn. Hark. Nats. named after V. N. Karazin. Collection of scientific works. - The series «Psychology». Whip 58. - 2015. - P. 147-151.

5. Soroka A. V. Psychological features of social readaptation of persons released from places of deprivation of liber- 
ty. Modern problems of applied legal psychology [Electronic resource]: materials I Resp. scientific-practical. Conf., Minsk, 23 November. - 2016 /red: I. A. Furmanov (editorial editors) [and others]. - Electron. Dan. (17.1 MB).

- Minsk: Izd. center of BSU, 2016.- P. 101-106.

6. Soroka A. V. Features resocialization of personality after release from serving the sentence. Social Sciences and Psychology faculty: 25 years (progress, problems, perspectives). Republican scientific-practical conference of young researchers (17 April 2017). - Bak1 - 2017. - P. 77-81.

7. Soroka A. V. PSYCHOLOGICAL FEATURES OF PERSONALITY SELF GOVERNING IN THE PERIOD OF SOCIAL REHABILITATION. Proceedings of III International scientific conference "Science: new goals". London, SI Universum, 2017. - P. 43-53.

8. Trubnikov $V$. M. Social adaptation of those who have been released from serving their sentences. Kharkov, 1990. - P. 3.

9. Shvalb Y. M. Psychology of social work: textbook / ed. Y. M. Shvalba. - K .: «Basis», 2014 - P. 30.

\section{Soroka Anatoly}

PhD, associate professor, Department of Applied psychology of V. N. Karazin National University, Kharkiv (Ukraine)

\section{EFFECTIVENESS OF THE PROGRAM PSYCHOLOGICAL CORRECTION RESOCIALIZATION OF INDIVIDUAL AFTER RELEASE FROM SERVING THE SENTENCE}

\author{
ABSTRACT \\ The conducted analysis of scientific litera- \\ ture convinces us that today in science enough \\ attention is paid to the psychodiagnostic and psy- \\ cho-corrective work on resocialization of the in- \\ dividual after the release from serving the sen- \\ tence.
}

Purpose of the article: to determine the individual results of the study after the application of our author's program of psychological correction of personal re-socialization after release from serving the sentence.

The research was conducted on the basis of four relevant institutions of Kharkiv and Sumy regions of Ukraine. The sample of the study is a total of 100 males (the first six months after the release of serving a sentence). 48 of them were selected out of it, which by their own will included up to four experimental groups and met the following criteria:

1) their internal convictions regarding changes in their own lives for the better were so desirable that they with great pleasure participated in the testing of the psycho-correction program;

2) the absence of narcotic, alcohol or gambling addiction;

3) subjects in groups were close by age.

They were given an opportunity to take part in group work for 2.5 months for 1 class weekly for 4 academic hours each (only 36 hours).

Thus, 4 experimental groups were formed:

- the first group of subjects (youth) -24 men, aged from 28 to 39 years - is divided into 2 subgroups of 12 people;

- the second group of subjects (older than age) - 24 men, aged 40 to 50 years - is divided into 2 subgroups of 12 people.

The total number of experimental experi- 
mental groups is 48 people.

The control group consisted of 52 subjects who were included in the sample at the initial stage of the study but did not participate in the group work; with them in different institutions of social adaptation, another work on resocialization was carried out.

It should be emphasized that psychocorrective training did not involve the participation of persons with pathopsychological deviations.

The practical significance of the research is to test and validate the results of the research (confirmed by the implementation acts), namely: «Psychodiagnostic and psycho-correction programs for the study of readiness for resocialization of the individual after being released from serving the sentence» in the centers of social adaptation of the Kharkiv and Sumy regions of Ukraine. The results of the study are used in the practical work of psychologists of penitentiary institutions, probation of the aforementioned areas, as well as during training in the system of professional training and professional development of psychologists of penitentiary institutions and probation of Ukraine.

Materials of research can be used in work with juvenile offenders; with convicts serving sentences in colony settlements or without isolation from society; in such spheres of psychology as legal, preventive, juvenile and others.

We hypothesize that the negative indicators of the aforementioned variables result in in- sufficient resocialization of the individual after being released from serving the sentence in modern society proved by us in the process of psycho -correction work with 4 experimental groups of the subjects studied. As a result of the work, there have been significant changes in a number of indicators of the system complex we are investigating, the severity of which at the time of completion of the study compared with its beginning allows us to assert that the process of resocialization of the subjects is successful. Eight of those who studied after participating in the program successfully married (material assistance provided to them by the relevant charitable and religious organizations of Ukraine) and happily living in the family, bringing up children. And the author as the head of the public organization of the North-East interregional department for the execution of punishments and probation of the Ministry of justice of Ukraine in every possible way tries to provide them with assistance.

The prospect of our further research and publications will be the disclosure of the results of the work after a psycho correction program with the researchers.

Key words: system approach, systemcomplex, psycho-correction program, resocialization of personality. 


\section{Сорока Анатолий Владимирович}

Кандидат психологических наук, доиент, доцент кафедры прикладной психологии Харьковского начионального университета имени В. Н. Каразина, г. Харьков (Украина)

\section{РЕЗУЛЬТАТИВНОСТЬ ПРОГРАММЫ ПСИХОЛОГИЧЕСКОЙ КОРРЕКЦИИ РЕСОЦИАЛИЗАЦИИ ЛИЧНОСТИ ПОСЛЕ ОСВОБОЖДЕНИЯ ОТ ОТБЫВАНИЯ СРОКА НАКАЗАНИЯ}

Аннотация. Проведенный анализ научной литературы убеждает нас в том, что сегодня в науке недостаточно внимания уделяется именно психодиагностической и психокоррекционной работе по ресоциализации личности после освобождения от отбывания срока наказания.

Цель статьи: определить отдельные результаты исследования после применения нами авторской программы психологической коррекции ресоциализации личности после освобождения от отбывания срока наказания.

Исследования проводились на базе четырех соответствующих учреждений Харьковской и Сумской областей Украины. Выборка исследования составляет общим количеством 100 человек мужского пола (первые шесть месяцев после освобождения от отбывания срока наказания). Из нее выделились 48 испытуемых, которые по собственному желанию входили в четыре экспериментальных группы и отвечали следующим критериям:

1) их внутренние убеждения относительно изменений своей жизни к лучшему были настолько желанными, что они с большим удовольствием участвовали в проведении апробации психокоррекционной программы;

2) отсутствие наркотической, алкогольной или игровой зависимости;

3) исследуемые в группах были близки по возрасту.

Им была предоставлена возможность участвовать в групповой работе в течение 2,5 месяцев по 1 занятию в неделю продолжительностью 4 академических часа каждое (всего 36 часов).

Таким образом, было сформировано 4 экспериментальные группы:

- первая группа испытуемых (молодежь) - 24 мужчины в возрасте от 28 до 39 лет - делятся на 2 подгруппы по 12 человек;

- вторая группа испытуемых (старшие по возрасту) - 24 мужчины в возрасте от 40 до 50 лет - делятся на 2 подгруппы по 12 человек.

Общее количество исследуемых экспериментальных групп составляет 48 мужчин.

Контрольную группу составили 52 испытуемые, которые вошли в выборку на начальном этапе исследования, но не принимали участия в групповой работе; с ними в различных учреждениях социальной адаптации проводилась другая работа по ресоциализации.

Следует специально подчеркнуть, что в психокоррекционной работе не участвовали лица, имеющие патопсихологические откло- 
нения.

Практическая значимость исследования заключается в апробации и успешном внедрении результатов исследования (подтверждено актами внедрения), а именно: «психодиагностической и психокоррекционной программами исследования готовности к ресоциализации личности после освобождения от отбывания срока наказания» в центрах социальной адаптации Харьковской и Сумской областей Украины. Результаты исследования используются в практической деятельности психологов учреждений исполнения наказаний, пробации вышеназванных областей, а также при проведении занятий в системе профессиональной подготовки и повышения квалификации психологов учреждений исполнения наказаний, пробации Украины.

Материалы исследования могут быть использованы в работе с несовершеннолетними правонарушителями; с осужденными, отбывающими наказание в колонии-поселении или без изоляции от общества; в таких сферах психологии, как юридическая, превентивная, ювенальная и другие.

Высказанная нами гипотеза о том, что негативные показатели вышеперечисленных переменных обусловливают недостаточную ресоциализацию личности после освобождения от отбывания срока наказания в современном обществе доказана нами в процессе психокоррекционной работы с 4-мя экспериментальными группами испытуемых. В результа- те работы произошли существенные изменения в целом ряде показателей исследуемого нами системо-комплекса, выраженность которых на момент завершения исследования по сравнению с его началом дает возможность утверждать, что процесс ресоциализации исследуемых происходит успешно. Восемь исследуемых после участия в программе успешно женились (материальную помощь им оказали соответствующие благотворительные и религиозные организации Украины) и счастливо живут в семье, воспитывают детей. А автор как председатель общественной организации Северо-Восточного межрегионального управления исполнения наказаний и пробации Министерства юстиции Украины всячески пытается оказывать им помощь.

Перспективой наших дальнейших исследований и публикаций будет раскрытие результатов работы после проведения психокоррекционной программы с исследуемыми.

Ключевые слова: системный подход, системо-комплекс, психокоррекционная программа, ресоциализация личности.

Дата отримання статті: 01.01.2018 Дата рекомендації до друку: 25.01.2018 